\title{
Honour killing: a socio-legal analysis with special reference to district Srinagar of J\&K
}

\begin{abstract}
Honour crime is a vintage crime which still holds its place in today's society inspite of the modern mindset and advance thinking. Honour killing is the most aggravated form of honour crime which is prevalent almost in all the societies of the world with variation in its statistics. Laws in some countries have totally banned honour killing and is regarded as one of the heinous crimes. As far as India is concerned it has no proper and accurate law to deal with such crimes, because of which a big lacuna has been developed in the Indian legal system. Jammu and Kashmir is also following the footsteps of India and its legal system is also silent about such a terrible crime which is done on the name of honour. In this paper an attempt has been made to highlight the statics relating to the aspects of honour killing like how people react to it? What law is? What law ought to bean many other questions which are important to deliberate upon for analysis of this problem?
\end{abstract}

Volume 2 Issue 4 - 2018

Gulafroz Jan, Khazin Munir

Department of Law, School of Legal Studies, Central University of Kashmir, India

Correspondence: Gulafroz Jan, Department of Law, School of Legal Studies, Central University of Kashmir, Srinagar, J\&K, India, Tel+919622689500, Email gulafrozjan@gmail.com

Received: February 16, 2018| Published: August 23, 2018

\section{Introduction}

Honour killing is a killing of a person on the name of Honour. Such a killing is done to save the prestige of a family or done in order to make it an example for other or done out of rage and anger, reason can be many. Some of the main reasons are marriage out of caste, divorce, marriage by choice, homosexuality, pregnancy before marriage, inappropriate dressing etc. Honour killing is a global phenomenon. The incidence of honour killings is very difficult to determine and estimates vary widely. In most countries data on honour killings is not collected systematically, and many of these killings are reported by the families as suicides or accidents and registered as such. Although honour killings are often associated with the Asian continent, especially the Middle East and South Asia, they occur all over the world. In 2000, the United Nations estimated that 5,000 women were victims of honour killings each year. ${ }^{1}$ According to BBC, "Women's advocacy groups, however, suspect that more than 20,000 women are killed worldwide each year." Murder is not the only form of honour crime, other crimes such as acid attacks, abduction, mutilations, beatings occur; in 2010 the UK police recorded at least 2,823 such crimes.

The extend of honour killing varies from state to state and country to country. India inspite being one of the highest rated countries in regard of honour killing, still all its states are not involved in this barbaric practice except (Punjab, Haryana, Rajasthan, Delhi, Bihar etc). In India Punjab is the most notories state in this regard with highest rate of honour killing cases because of the presence of 'Khap Panchayat' or 'Caste panchayat'. One of the landmark judgments in India on the crime on honour killing was given by the court in the case of Manoj-Babli honour killing case. On March 2010, the accused were sentenced for capital punishment. In the state of Jammu and Kashmir no official survey has been yet made on the extent of honour killings, but the state of Jammu and Kashmir is also no free from the curse of honour killing. Most of the cases go unreported because of the influence of the family or are reported as suicides or accidents. The alarming rate of suicide incidences amongst youth in Kashmir serves as an escape path for such honour killings. In the first reported case of 'honour killing' in Kashmir was in budgam area where the police had arrested a man and his two sisters on the charge of murdering their youngest sibling over her conduct. Mushtaq Ahmad Dar and his two sisters-Nasreen and Misra-were arrested after the trio admitted to strangulating their 20-year-old sister Zubaida to death because she was in affair with a boy whom his family didn't approve off. In the backdrop of the situation the researcher has carried out present research with two broad objectives:

1. To analyse the present legal position and judicial approach on honour killing in india and state of $\mathrm{J} \& \mathrm{~K}$

2. To analyse by way of empirical study the society's idea about the concept of honour killing, and adequacy of laws in the state of $\mathrm{J} \& \mathrm{~K}$.

\section{Different laws in India pertaining to honour killing}

\section{The Indian Penal Code ${ }^{2}$}

\section{Section 300}

MURDER -(Firstly) - Except in the cases hereinafter excepted, culpable homicide is murder, if the act by which the death is caused is done with the intention of causing death, or

(Secondly) - If it is done with the intention of causing such bodily injury as the offender knows to be likely to cause the death of the person to whom the harm is caused, or

(Thirdly) - If it is done with the intention of causing bodily injury to any person and the bodily injury intended to be in $\neg$ flicted is sufficient in the ordinary course of nature to cause death, or

(Fourthly) - If the person committing the act knows that it is so imminently dangerous that it must, in all probability, cause death or such bodily injury as is likely to cause death, and commits such act without any excuse for incurring the risk of causing death or such injury as aforesaid.

To relate Honour killing with $\operatorname{Sec} 300$ it has to be seen whether a killing is based on honour or not. Generally Honour killing is pre-planned, premeditated, well executed with the connivance of family members, society and sometimes with the assistance of police officers. Thus the Act of Honour killing squarely falls under section 
300 of Indian penal code. ${ }^{3}$ Every Honour Killing is primarily and essentially a murder but vice versa is not correct. Only that murder wherein the objective of killing is to protect family honour or protect the sanctity of wrong traditions prevailing in the societies or the communities, fall within the sphere of honour killings. Since crime of honour killings falls within the board provisions of murder deserving harsher penalties. But there are certain exceptions to the offence of murder. One of the exceptions which is usually invoked for getting mitigated punishment in Honour killing cases in the defence of grave and sudden provocation. ${ }^{4}$

\section{Constitution of India}

It also violates Articles 14, 15 (1) \& (3) 19 and 21 of the Constitution of India. Article 14 of the Indian Constitution guarantees to every person the right to equality before the law or the equal protection of the laws. Every person, whatever is his rank or position or gender is subject to the jurisdiction of the ordinary courts. ${ }^{5}$ The equal protection of the laws', is rather a corollary of the first expression ${ }^{6}$ and is based on the last clause of the first section of the fourteenth amendment to the American constitution, directs that equal protection shall be secured to all persons within the territorial jurisdiction of union in the enjoyment of their rights and privileges without favoritism or discrimination. Honour Killings are thus grossly against this very constitutional right provided for the protection of citizens. As already stated earlier, honour killings are mainly directed towards woman and thus give rise to gender inequality. This brings us to Article 15 of the Indian constitution. Article 15(1) prohibits the state from discriminating against citizens on grounds only of religion, race, sex, caste, and place of birth or any of them. The right guaranteed in clause (1) is conferred on a citizen as an individual, and is available against his being subjected to discrimination in the matter of rights, privileges and immunities pertaining to him as a citizen generally. ${ }^{7}$ However in many communities across India where Honour killing is prevalent, wives and daughters are expected to be subordinate, even servile, to their fathers and husbands, and even their own sons. Women's role in life is ancillary: as a dutiful daughter, an obedient wife and a selfsacrificing mother. ${ }^{8}$

It is also violation of Article 19 and Article 21 of the Constitution. Such brutal murders, under the garb of saving the honour of the family, are clearly against the Constitutional provisions enshrined in Article 21. Khap panchayats violate a person's fundamental right to life when they pass orders to kill or instigate murder, in the name of honour. ${ }^{9}$

\section{The Indian majority Act, I $857^{10}$}

According to section 3 of the Indian Majority Act, 1857 every person domiciled in India shall attain the age of majority on completion of 18 years, unless his or her personal law specifies otherwise. However, in the case of guardian appointed to such minor, age of majority will be 21 and not 18 year. The Act becomes relevant in cases where the khap panchayats have forcefully separated married couples, who are otherwise eligible for such marriage due to age etc. This is a clear case of violation of the provisions under this Act.

\section{The special marriage Act, $1954^{\prime \prime}$}

Here it is important to note that the main reason for the enactment of the Special Marriage Act, 1954 was to provide a special form of marriage for the people of India and all Indians residing in foreign countries, irrespective of the religion or faith followed by either party, to perform the intended marriage.

\section{The scheduled castes and scheduled tribes (Prevention of Atrocities) Act, $1989^{12}$}

This Act was enacted by the Parliament of India, in order to prevent the cases of atrocities against Scheduled Castes and Scheduled Tribes. The objective of the Act was to facilitate the social inclusion of Dalits into mainstream of the Indian society. The atrocities under this Act includes various acts such as forcing an SC/ST to eat or drink any inedible or obnoxious substance, removing clothes, parading naked or with painted face or body, assaulting, dishonouring and outraging the modesty of an SC/ST woman, sexual exploitation of an SC/ST woman, forcing an SC/ST to leave his or her house or village as punishable. The Act is linked to honour killings because numerous incidents of honour killing are in relation to caste and religion.

\section{The protection of women from domestic violence Act, $2005^{13}$}

The provisions of the Protection of Women from Domestic Violence Act, 2005 provides for more effective protection of the rights of women guaranteed under the Constitution who are victims of violence of any kind occurring within the family and for matters connected therewith or incidental thereto.

\section{Indian evidence Act, $1872^{14}$}

Further the Indian Evidence Act, 1872 provides punishment for those who are involved in concealment of facts, either before or at the time of, or after the alleged crime. Article 13 of the Act: Facts relevant when right or custom is in question - Where the question is as to existence of any right or custom, the following facts are relevant: (a) Any transaction by which the right or custom in question was created, claimed modified, recognized, asserted or denied, or which was inconsistent with its existence; (b) Particular instances in which the right or custom was claimed, recognized, or exercised, or in which its exercise was disputed, asserted, or departed from. The Act is relevant to bring to justice those who become victim because of the verdicts issued by the khap panchayats.

\section{Difference between homicide and honour killing}

Homicides are no doubt grave crimes bur society may or may not be affected by the same by large, but Honour killing is a heinous crime and a greater evil which affects the society at large. In other words homicides may affect public interest whereas the offence of Honour killing shakes Public conscience. ${ }^{15}$ In case of homicides there are several exceptions which are mentioned in IPC but in case of Honour killing, it is pre- planned, brutally executed more often than not within blood relations and that too in connivance with the law enforcing agencies, therefore the defence should not be made ordinarily available and are not ordinarily justified in the eyes of law. ${ }^{16}$ Honour killings in India occur because of certain age old practices like casteism, religions, traditions, cultures etc, whereas there is no such criterion for homicides. Motives for killing here may be varied and sometimes justified. In Honour killings the offender is usually also the victim because of the fact the deceased/primary victim on whom violence is usually committed are usually related by blood and in this sense the offender is victim as well, where as it not usually so in homicide. ${ }^{17}$ The above difference make the crime of honour killing different from general homicides and thus deserve special treatment for prohibiting, punishment and preventing such crimes. 


\section{Honour killing and judicial approach}

The judicial trends reflect a change from its earlier approach, that can be appreciated, from the various judgments of the Courts, we can say that now, the Honour killings are not termed differently. Courts through their judgments had reiterated that killing anyone in the name of honour in the violation of the Constitution of India and anyone going contrary to the Constitution will be punished. In a landmark judgment in March 2010, the Karnal District Court ordered the execution of the five perpetrators in an honour killing case of Manoj and Babli, while giving a life sentence to khap (Local caste based Council) head who ordered the killings of Manoj Banwala (23) and Babli (19), two members of the same clan who eloped and married in June 2007 and later their mutilated bodies were found a week later from an irrigation canal. In her verdict, district Judge Vani Gopal Sharma stated, - This Court has gone through sleepless nights and tried to put itself in the shoes of the offenders. Khap Panchayats have functioned contrary to the Constitution, ridiculed it and have become law into themselves. The case was both the first court judgment convicting khap panchayats and the first capital punishment verdict in an honour killing case in India. The India media and legal experts hailed it as a -landmark judgmentll. Also, few honour killing cases go to the Court, and this is the first case in which the groom's family in an honour killing case filed the case. ${ }^{18}$

The Supreme Court in State of U.P. vs Krishna Master and anr, ${ }^{19}$ awarded life sentence to three persons in an honour killing case, in which six members of a family were gunned down, but said the accused deserved capital punishment. The apex court however, refrained from awarding death penalty to Master Krishna, Ram Sewak and Kishori as the incident was two decades old and slammed the High Court for acquitting them by rejecting the testimonies of a child and another witnesses. Next important case on the issue is of Lata Singh vs State of U.P. and $\mathrm{Anr}^{20}$ where the Division Bench of the Supreme Court expressed concern over the several instances of harassment, threats and violence against young men and women who marry outside their caste and held that "such acts or threats or harassment are wholly illegal and those who commit them must be severally punished". Observing that "inter-caste marriages are in fact in the national interest as they will result in destroying the caste system", the Bench held that "once a person becomes a major he or she can marry whosoever he/she likes. If the parents of the boy or girl do not approve of such inter-caste or inter-religious marriage the maximum they can do is that they can cut off social relations with the son or the daughter, but they cannot give threats or commit or instigate acts of violence and cannot harass the person who undergoes such inter-caste or inter-religious marriage." Accordingly, the Bench directed the administration/police authorities throughout the country to see to it "that if any boy or girl who is a major undergoes inter-caste or inter-religious marriage with a woman or man who is a major, the couple are not harassed by any one nor subjected to threats or acts of violence, and anyone who gives such threats or harasses or commits acts of violence either himself or at his instigation, is taken to task by instituting criminal proceedings by the police against such persons and further stern action is taken against such persons as provided by law." Referring to instances of 'honour killings' of persons undergoing inter-caste or interreligious marriage of their own free will, the Bench said "there is nothing honourable in such killings, and in fact they are nothing but barbaric and shameful acts of murder committed by brutal and feudal minded persons who deserve harsh punishment."
In the case of Fiaz Ahmed Ahanger and ors. vs. State of J and $\mathrm{K},{ }^{21}$ it was held that: "In such cases of inter-caste or inter religion marriage the Court has only to be satisfied about two things: (1) That the girl is above 18 years of age, in which case, the law regards her as a major vide Section 3 of the Indian Majority Act, 1875. A major is deemed by the law to know what is in his or her welfare. (2) The wish of the girl.

Similar observations were made in the case of Jyoti Alias Jannat and Anr vs State of UP and others, ${ }^{22}$ wherein it was held that according to Indian Majority Act 1875 a person who is 18 years of age is a major vide section 3 of the Act. The law deems that a major understands his / her welfare. Hence a major can go wherever he /she like and live with anybody. India is a free, democratic, welfare country. Hence if a person is major even parents cannot interfere with that individual. Once a person becomes a major that person cannot be restrained from going anywhere and live with anyone. Individual liberty under Article 21 has the highest place in the constitution.

Further in Arumugam Servai vs. State of Tamil $\mathrm{Nadu}^{23}$ the Supreme Court strongly deprecated the practice of khap/katta panchayats taking law into their own hands and indulging in offensive activities which endanger the personal lives of the persons marrying according to their choice. The Hon'ble Supreme Court observed and directed:- "We have in recent years heard of "Khap Panchayats" (known as "Katta Panchayats" in Tamil Nadu) which often decree or encourage honour killings or other atrocities in an institutionalised way on boys and girls of different castes and religion, who wish to get married or have been married, or interfere with the personal lives of people. We are of the opinion that this is wholly illegal and has to be ruthlessly stamped out.

As already stated in Lata Singh case, there is nothing honourable in honour killing or other atrocities and, in fact, it is nothing but barbaric and shameful murder. Other atrocities in respect of personal lives of people committed by brutal, feudal-minded persons deserve harsh punishment. Only in this way can we stamp out such acts of barbarism and feudal mentality. Moreover, these acts take the law into their own hands, and amount to kangaroo courts, which are wholly illegal. The court issued direction to the administrative and police officials to take strong measures to prevent such atrocious acts. The court said that in the event taking place, the state should immediately institute criminal proceedings against those responsible for such atrocities, the State Government is directed to immediately suspend the District Magistrate/Collector and SSP/SPs of the district as well as other officials concerned and charge-sheet them and proceed against them departmentally if they do not (1) prevent the incident if it has not already occurred but they have knowledge of it in advance, or (2) if it has occurred, they do not promptly apprehend the culprits and others involved and institute criminal proceedings against them, as in our opinion they will be deemed to be directly or indirectly accountable in this connection" The Supreme Court in another Judgement, Bhagwan Dass vs State of NCT of Delhi ${ }^{24}$ again reiterated that in our country unfortunately 'honour killing' has become common place, as has been referred to in our judgment in Arumugam Servai vs. State of Tamil Nadu. ${ }^{25}$

Many people feel that they are dishonoured by the behaviour of the young man/woman, who is related to them or belonging to their caste because he/she is marrying against their wish or having an affair with someone, and hence they take the law into their own hands and kill or physically assault such person or commit some other atrocities on them. We have held in Lata Singh vs. State of U.P. \& Anr. ${ }^{26}$ that this is wholly illegal. 
The Hon'ble Supreme Court while laying down the proposition that the so-called honour killing comes within the category of rarest of the rare cases deserving death punishment. It was observed "this is necessary as a deterrent for such outrageous, uncivilized behaviour. All persons who are planning to perpetrate „honour killing" should know that the gallows await them". This decision in Bhagwan Das vs. State (NCT of Delhi) [(2011) 6 SCC 396] as well as the decision in Arumugam Servai (supra) were rendered by the same Bench. A copy of the judgment was directed to be sent to all the High Court's who shall circulate the same to all the Sessions Judges. Following this judgment, in the recent times, as seen from the newspaper reports, almost all the accused in the so-called honour killing murder cases were sentenced to death by the Sessions Courts in U.P. and Delhi.

Law Commission's View - on the According to Law Commission ${ }^{27}$ such a blanket direction given by the Supreme Court making death sentence a rule in-honour killings\| cases, makes a departure from the principles firmly entrenched in our criminal jurisprudence by virtue of a series of decisions rendered by larger Benches of Supreme Court, for e.g. Bachan Singh vs. State of Punjab and Machhi Singh vs. State of Punjab. It is settled law that aggravating and mitigating circumstances should be weighed and it is only in very exceptional and rare cases, death sentence should be imposed. Death sentence, in other words, is a last resort. Further, where there is more than one accused, the degree of participation and culpability may vary. It is needless to emphasise that each case must be judged by the facts and circumstances emerging in that case. No hard and fast rule can be laid down in the light of the Supreme Court's consistent approach towards death sentence vs. life imprisonment issue. This judgment in the case of Bhagwan Das is bound to create uncertainty in the state of law and we are sure that in the near future, the correctness of such proposition will be tested by a larger Bench of Hon'ble Supreme Court.

State of U.P through the C.B.I v. Rajesh talwar \& others. ${ }^{28}$ On 25 th of November, 2013 sessions court in Ghaziabad announced its verdict in Arushi murder case declared Rajesh Talwar and Nupur Talwar guilty of killing their daughter Arushi and the servant Hemraj in May 2008. 13- year old Arushi was found with her throat slit open in her bedroom at Talwar Noida apartment. After declaring domestic helper Hemraj, who was missing, a prime suspect, the servant's corpse was found on the terrace. The Ghaziabad sessions court held both the Talwar guilty of double murder. Both of them were convicted under honour killing where her father killing her in a fit of rage after finding her with Hemraj in an objectionable position. ${ }^{29}$ Court later decided that the parents should be given benefit of doubt and they were released but after their release CBI has filed an appeal in Supreme Court against the judgement of Delhi high court.

Bhavna yadav Honour killing ${ }^{30}$ - In a horrific case of "honour killing" in the capital, a 21-year-old final year student of Sri Venkateswara, a leading college in Delhi University's south campus, was allegedly murdered by her family because she had married a boy from another caste and region. The victim, Bhavna, was allegedly strangled by her parents and uncle at their southwest Delhi home after which her body was taken to her hometown, Alwar, and quietly cremated, police said. Her parents-Jagmohan, a property dealer and local Congress party member, and Savitri-have been arrested. Bhavna had on November 12 got married at an Arya Samaj temple to Abhishek Seth, 24, an assistant programmer at the Cabinet secretariat. Bhavna was a Yadav from Rajasthan while Abhishek is a Punjabi. Sankar murder case, $12 \mathrm{dec}, 2017^{31}$ - In a sensational case of honour killing, Tamil Nadu's Tirupur Principal District and Sessions Court on Tuesday sentenced six persons to double death penalty for the daylight murder of 23-year-old dalit V Sankar who had married an upper caste woman. The murder took place in a busy marketplace and was caught on CCTV cameras. Of the 11 accused, six including girl's father Chinnasamy received death penalty, one person was awarded double life sentence, one person got at a five-year sentence and three including girl's mother Annalakshmi were acquitted.

This part of research is exclusively pertains to the empirical study which has tried to ascertain some facts relating to honour killing on ground level. Society's idea about this concept and its reaction towards this problem is recorded in the analysis done in this chapter. This chapter comprises of the field work and assembling of the idea pertaining to the topic of honour killing. That data gathered from the respondents is expressed in percentage through pie charts. The data received is interpreted and analyzed in the light of the doctrinal as well as non doctrinal part of the study.

\section{Universe of the study}

As lime light in the introductory chapter of the research study, the universe of the study for non doctrinal part of the research comprised of Srinagar, district of Jammu and Kashmir. Srinagar being the urban district of Kashmir and being the most versatile of all districts makes it a hub of all the activities including trade, tourism, manufacturing factories etc. So the responses gathered from this district are diverse. Rural people have a close mind set because of the pre-established norms of the society while as in urban areas mind sets changes with the environment and a person can think out of his cocoon in which he was living. Srinagar has a mixed population which comprises of almost all the districts of Kashmir, which makes it a complex sphere where you will get each and every variety of people from rich to poor, from old to young from educated to uneducated etc. Every person who has a different mindset may or may not change with the environment and Srinagar has this beautiful orah in it which absorbs all the mindsets, cultures and all the people who come from different spheres of life.

\section{Research tools used for field work}

\section{Questionnaire}

Questionnaire is a tool of research methodology in which some questions are short listed and in a given formatted it is distributed between the subjects to get there response. For this chapter a close ended questionnaire was framed with few options amongst which the subject had to make a choice.

\section{Sampling and the Strata}

\section{Stratified Random sampling}

Sampling which has been done is a stratified random sampling. First a strata is identified like that of teachers or lawyers or any other group which would prove fruitful to the research and then random sampling was done.

\section{Strata's identified}

\section{Teachers, students, professionals}

Teachers where short listed for this research because these are the knowledge givers to a society. Teachers have a major role in building the future of any country through their students so it was important to 
know what they know about this problem and how they are imparting knowledge of such a heinous crime amongst their students. Students are the building blocks and future of tomorrow so their opinion is of great importance in such a social issue as they can make or break the future. Professionals where consulted because everyone has an expertise in his/her filed and such a social problem pertains to all the professions. Researcher was keen to know whether professions have a way out to such a problem or any advice for the problem by applying their expertise.

\section{Lawyers, judges, law officers}

Lawyers are the most important subjects when it comes to any social issue. Lawyers are those people who fight for an issue or are against it and in both the ways their role is very sensitive and always prone to criticism or support or debate. A lawyer fighting in support of honour killing and fighting against honour killing both make the society aware of the rules and laws pertaining to the same. Judges are the people who make a precedent. They are seen as the justice givers which increases their status in society above all. Their judgments makes way for the new cases and their approach towards such a problem fixes the seriousness of a problem. Law officer is an officer who is aware of the legal aspect of the problem and how to deal with it. He also plays a Vitol role in social issues.

\section{Religious experts like imam, pujaries}

Imams and pujaries belong to that sect of the society were even today they are regarded as the most respectable citizens of the society and their orders/requests/commands are still followed and obeyed. These people have an influential power which generally prevails over the society and because of this power their point of view on such an issue is needed and can help the researcher to find out new experiences.

Representation in the shape of Pie chart of all the questions asked in the questionnaire

Killing in the name of Honour has become a common phenomena

Out of 200 respondents, $37 \%$ agree on the fact that it's a common phenomena, $24 \%$ strongly agree, $23 \%$ regard it not to be a common phenomena, $3 \%$ strongly disagree of it being a common phenomena and $13 \%$ respondents had no idea of this concept so they had no opinion about it.

\section{What is your source of knowledge about Honour killing?}

Out of 200 respondents, $45 \%$ got the information about honour killing from print media (newspaper, magazine, journals etc) , 33\% of the respondents got the information from electronic media ( Television, radio, social sites etc), $14 \%$ got the information from their locality, $7 \%$ of the respondents got the information from their family and $1 \%$ from peer groups.

\section{Have you seen or are you witness of any incident of} Honour killing?

Out of 200 respondents $68 \%$ response was in NO, $27 \%$ consented with YES and 5\% of the respondents were not aware of it so their response was CANT SAY.
What in your observation amongst the following behaviour/behaviours brings Dis-honour to the family?

Out of 200 respondents, $25 \%$ thinks that pre-marital sex or pregnancy brings dis-honour to the family, other $25 \%$ thinks that homosexual activities brings dis -honour to the family, $20 \%$ of the respondents believe that marriage outside family norms brings dishonour, 9\% think marriage by choice is a dis- honour in itself, $5 \%$ responded that intimacy/ friendship with distant relatives brings dishonour and other $5 \%$ responded that roaming with the strangers brings dis honour, $6 \%$ believe that arguing with elders brings dis honour to the family, $3 \%$ think that dressing in unacceptable manner brings dis honour to the family and $2 \%$ believe that remaining away from home without the permission of the elders brings dis honour to the family.

\section{Do you think the above mentioned reason/reasons justify the killing of a person?}

$24 \%$ of the responses from 200 respondents believe that the above mentioned reasons are justified for killing of a person, $27 \%$ strongly agree that the above mentioned reasons are jusfied, $30 \%$ believe that the above mentioned reasons are not justified for the killing of a person, $12 \%$ strongly disagree with the above mentioned reasons and $7 \%$ of the respondents have no knowledge of it.

\section{Does honour Killing revive the Honour of the Family?}

$19 \%$ respondents agree with the fact that honour killing revives the honour of the family, $13 \%$ strongly agree with this fact, $42 \%$ disagree with the statement that honour killing revives the honour of the family, $17 \%$ strongly disagree with the statement and $9 \%$ of the respondents were not able to say anything.

\section{Does family honour depend solely on the females of the family?}

$36 \%$ of the respondents agree that family honour solely depends on females of the family, $23 \%$ strongly agree that family honour depends on females of the family, $24 \%$ disagree and feel that honour doesn't solely depend on the female of the family, $3 \%$ strongly disagree with the statement and $14 \%$ of the respondents had no opinion on this point.

\section{Honour killing is more in un-educated families than in the educated families}

$37 \%$ respondents agree with the fact that honour killing is more in uneducated families rather than in educated families, $18 \%$ strongly agree with this fact, $30 \%$ disagree with the statement that honour killing is more in uneducated families rather than in educated families, $7 \%$ strongly disagree with the statement and $8 \%$ of the respondents were not able to say anything.

\section{Every person has a right to live a life in his/her own way}

$43 \%$ respondents agree with the fact that every person has a right to live in his/her own way, $24 \%$ strongly agree with this fact, $26 \%$ disagree with the statement that every person has a right to live his/ her in their own way, $3 \%$ strongly disagree with the statement and $4 \%$ of the respondents were not able to say anything as they had no knowledge about it or were not comfortable in giving response. 


\section{Every person has a right to choose his/her career}

$53 \%$ respondents agree that every person has a right to choose his/ her career $34 \%$ strongly agree with this fact, $9 \%$ disagree with the statement that every person has a right to choose his/her career, $3 \%$ strongly disagree with the statement and $1 \%$ of the respondents were not able to say anything.

\section{Do you think religion permits Honour killing?}

$17 \%$ respondents agree that religion permits honour killing, $28 \%$ strongly agree with this fact, $43 \%$ disagree with the statement that religion permits honour killing, 10\% strongly disagree with the statement and $2 \%$ of the respondents had no opinion regarding the same.

\section{Does a family member/ relatives have a right to kill the person who has brought shame to the family?}

$11 \%$ respondents agree with the fact that a family member has a kill the person who brings dis honour to the family, $13 \%$ strongly agree with this fact, $41 \%$ disagree with the statement that honour killing should be done by a family member of a person who brings dis honour to the family, $32 \%$ strongly disagree with the statement and $3 \%$ of the respondents have no opinion or answer to this question.

Do you feel that the Mohalla committee in J\&K plays the same role as that of Khap panchayat in case of Honour abuse and Honour killing?

$34 \%$ respondents agree that the mohalla committee in $\mathrm{j} \& \mathrm{k}$ plays the same role as that of Khap panchayat in case of Honour killing and Honour abuse, $11 \%$ strongly agree with this fact, $40 \%$ disagree with the statement , $6 \%$ strongly disagree with the statement and $9 \%$ of the respondents were not able to say anything or were not willing to give their response.

\section{The existing laws are sufficient to curtail the menace of honour killing}

$17 \%$ respondents agree with this fact that the exsisting laws on honour killing are sufficient, $28 \%$ strongly agree with the statement that existent laws are sufficient, $43 \%$ disagree with the statement that exsisting laws on honour killing are sufficient, $10 \%$ strongly disagree with the statement and $2 \%$ of the respondents were not able to say anything.

\section{The existing laws with relation to honour killing are implemented properly}

$10 \%$ respondents agree that the implementation of the exsisting laws on honour killing is being done properly, 5\% strongly agree with this statement, $35 \%$ disagree with the statement that exsisting laws are being properly implemented, $40 \%$ strongly disagree with the statement and $10 \%$ of the respondents have no knowledge of it.

There is a need to incorporate new laws with the relation to honour killing

$18 \%$ respondents agree that there should be incorporation of new laws with relation to Honour killing, $42 \%$ strongly agree with the concept of incorporation of new laws for honour killing, $6 \%$ disagree with the statement honour killing needs new law, 18\% strongly disagree with the statement and $18 \%$ of the respondents are unaware and have less knowledge about the same so they didn't respond to this question.

\section{Honour killings should be severely punished}

$20 \%$ respondents agree with the fact that the offence of honour killing should be severely be punished, 55\% strongly agree that honour killing should be severely be punished, $15 \%$ disagree with the statement that honour killing should be severely be punished, $8 \%$ strongly disagree with the statement and $2 \%$ of the respondents were not able to say anything.

\section{The personality of the judge gets reflected in his/her judgment relating to honour killing cases}

$18 \%$ respondents agree with the statement that the personality of the judges gets reflected in his/her judgment relating to Honour killing, $42 \%$ strongly agree with this statement, $6 \%$ disagree with this statement that personality of judges gets reflected in their judgment, $18 \%$ strongly disagree with the statement and $18 \%$ of the respondents have no idea about the same.

\section{Killing in the name of honour is justified in certain cases}

$28 \%$ respondents agree with the fact that honour killing is justified in certain cases, $22 \%$ strongly agree with this statement, $32 \%$ disagree with the statement that honour killing is justified in certain cases, $8 \%$ strongly disagree with the statement and $10 \%$ of the respondents have no knowledge or no idea or are not comfortable in answering the question.

\section{Research findings by data interpretation}

An overall evaluation of the findings of the research reveals that maximum people are aware of the concept of Honour killing and its existence. There are various motivations for honour killing like, love marriage, inter caste marriage, homosexuality, divorce, disobeying elders, arguing with elders, choice of clothes, roaming with people, staying away from home till late etc. It was also found that people have different perception of honour. How people perceive honour is affected by various factors like age, cultural background, education, faith, residence (rural or urban) and social relations and sometimes the economic factors as well. Some of the respondents perceived honour as the most important thing in their life. During the interview majority uttered that honour is the base thing of their life. This concept is not only supported by the elders of the society but some youngsters also adhere to the strict sense of honour and can go to any extend to safeguard the honour of their family. When respondents were asked about honour killing whether it has become a common phenomena or not $61 \%$ agreed amongst which $24 \%$ agreed strongly showing that our society is totally aware of the concept of honour killing and not just are aware they also have good knowledge about this phenomenon. $26 \%$ disagreed with the statement that honour killing is a common phenomenon amongst which $3 \%$ strongly disagreed which shows that maximum population is aware and thinks it as a common phenomenon. Only $13 \%$ of the respondents were not even aware of the term or concept of honour killing as they choose the option "Can't Say" (Figure 1). 


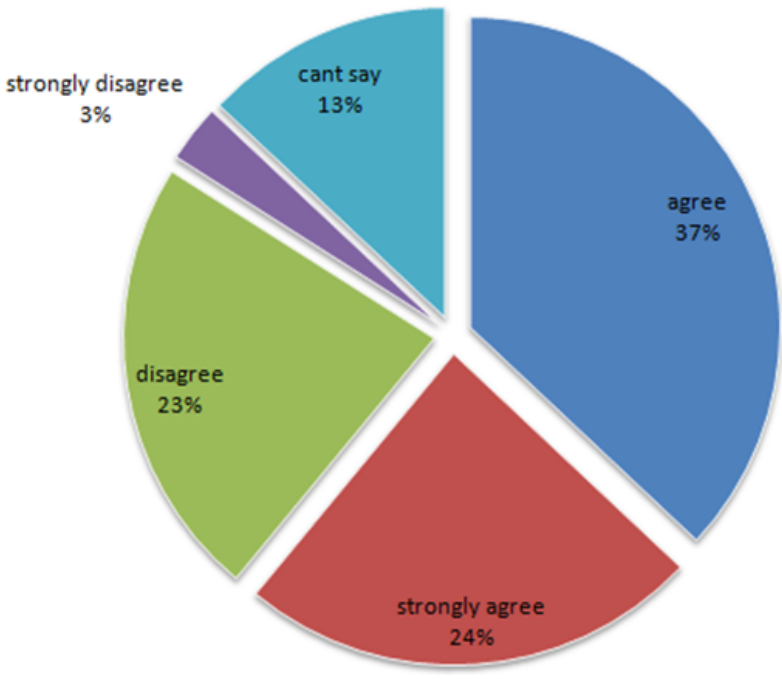

Figure I The percentage of the reaction of respondents on Honour killing as common phenomena.

When asked about the source from which the respondents have acquired their knowledge about honour killing, the response was that maximum respondents got the information from print media i.e. $45 \%$ which includes news papers, magazines, journals, articles, books etc. $33 \%$ selected electronic media which includes news channels, TV shows, radio news, debates on television/radio, social networking sites etc. In the world were electronic media is easily accessible and generally every person is online still maximum of the respondents source is print media which is bit of a surprise. $14 \%$ had the knowledge of honour killing because of their own locality, may be cause of the incidents which had taken place in their locality in past or present or because of some stories which they have heard about the same from their elders or friends or relatives. $7 \%$ of the people acquired the knowledge from their own family. Chances are that their elders must have told them about it or they would have themselves seen such situation or not exactly that situation but a condition closer to that (Figure 2).

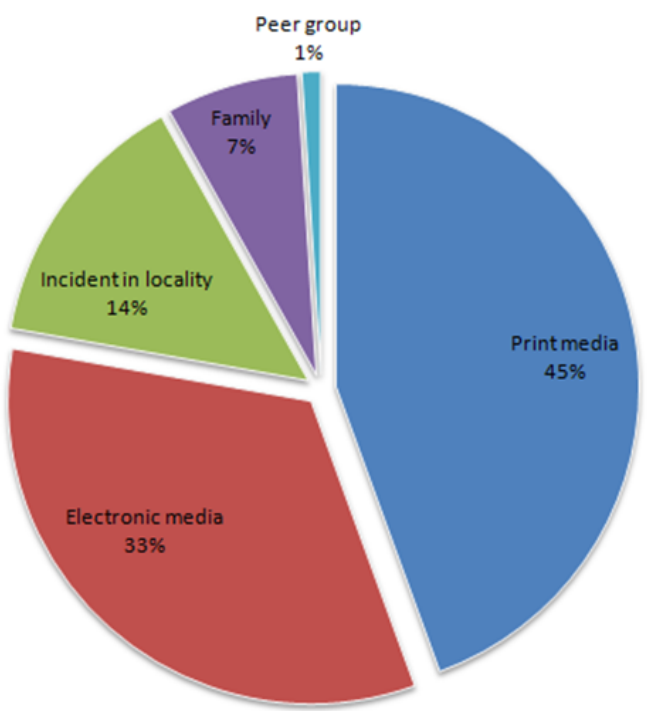

Figure 2 The percentage of the source of knowledge of the respondent.
When respondents were asked whether they have experienced of witnessed and incident of honour killing, majority of the respondents i.e. $68 \%$ said $N o$ which can be taken as a good sign that people have not experienced it and have not faced such a terrible situation in their lives but $27 \%$ replied in Yes which shows that in our society this heinous practice is being observed on an alarming rate as $27 \%$ for such a crime is not less and by this percentage it can be seen that the old traditions and old thoughts are still prevalent and are not done away with totally. The happiness which a person gets from the static of $68 \%$ is totally over shadowed by $27 \%$ as this percentage shows the existence, practice, preaching and propagation of such a brutal act. $5 \%$ of the respondents reply was Can't Say (Figure 3).

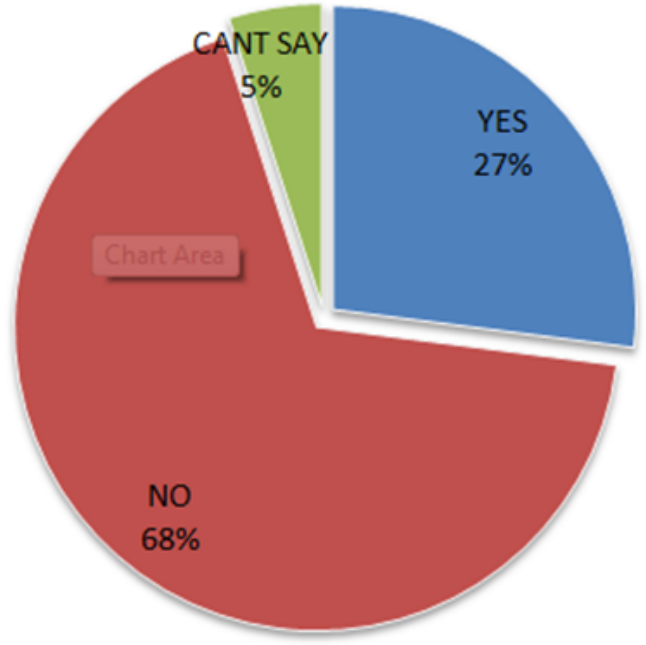

Figure 3 Shows whether respondent has witness any incident of Honour killing.

When inquired about the behaviour or behaviours which can lead to dis honoring or harming the honour of a family, the response was a bit divided between pre-marital sex/pregnancy before marriage and homosexuality and both got the response of $25 \%$ each. This means that our society takes pre-marital sex or pregnancy and homosexuality as the gravest act which a person can perform to bring shame to his/ her family. $20 \%$ responded with the view that marriage outside family norms brings dishonour to the family and this reason has been one of the biggest reasons in India which has lead to honour killing. Even the three registered cases of honour killing in Kashmir are also due to marriage our side family norms or by choice marriage. So this percentage states that total $70 \%$ of the respondents feel that their honour will get ruined cause of premarital sex/pregnancy, homosexuality and marriage outside family norms. $9 \%$ of respondent think that marriage by choice is the reason by which a family can be dishonoured, which leads to the concept of marriages within the casts or within the same community. $6 \%$ of the respondents have an opinion that if children or the youngsters argue with their elders than it is disgraceful and their honour in ruined by that. Intimacy with relatives and roaming with strangers got a response of $5 \%$ each and $3 \%$ of the total respondent's views was that the inappropriate or unacceptable dressing sense will lead to dishonour of a family. This $3 \%$ in itself clears that our society is adopting the modern dressing and western trends in their day to day activates and there are just few who are not convinced with the idea of modernization. $2 \%$ of the respondents believe that remaining away from home without the permission of elders is disgraceful and brings dishonour to the family (Figure 4). 


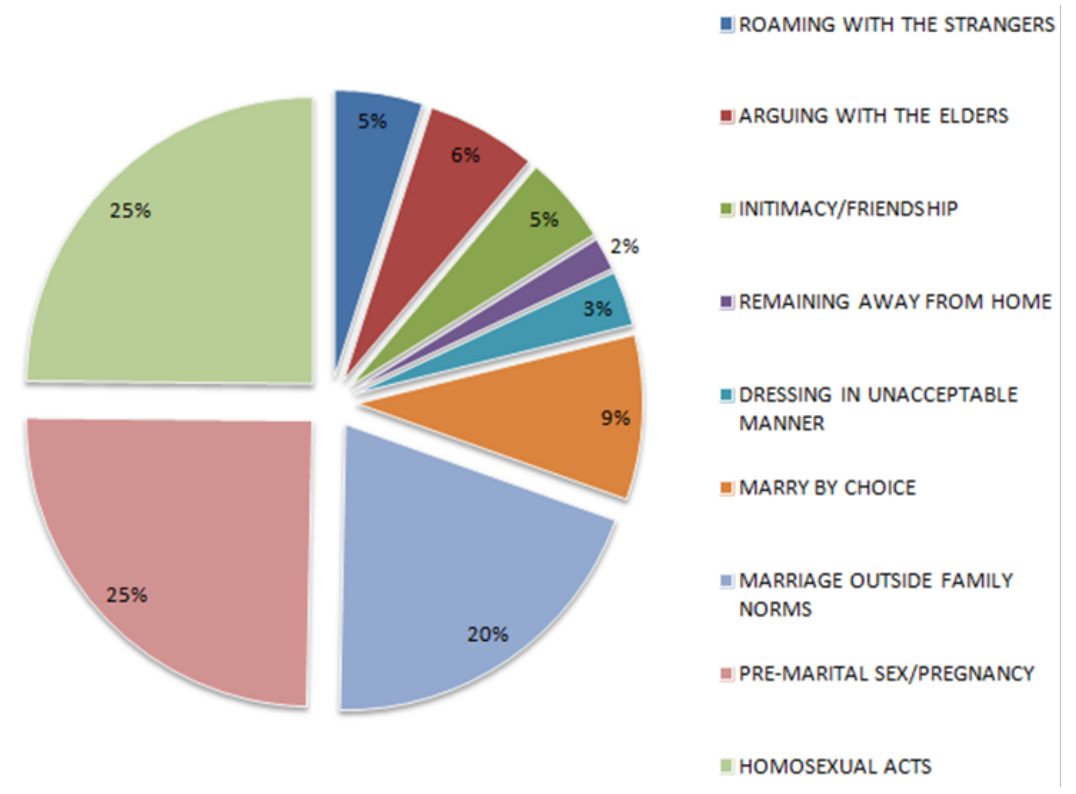

Figure 4 Responses on different behaviour which can bring dis-honour to family.

When the respondents were asked whether the above mentioned reasons/reason give a person or a family member right to kill a person then the response came as a shock to the researcher because $51 \%$ agreed amongst which $27 \%$ strongly agreed making this view a stronger view of the general public which was generally not expected by the researcher. These statistics came as an eye opener to the pre conceived notion of the maximum people who have studied about it or who research on such topic. 51\% means more than half of the respondents which makes it superior view and gives a clear picture of the society which still believe in elimination the person from the society totally than adopting his/her ways or his/her way of living. This percentage defends the statement that "You are not living alone, but you live in a society". $42 \%$ disagree and believe that these reasons don't give right to any person to kill another person and amongst this percentage $12 \%$ strongly disagree with such a statement. $7 \%$ of the respondents didn't comment on it and gave a response which was Can't Say (Figure 5).

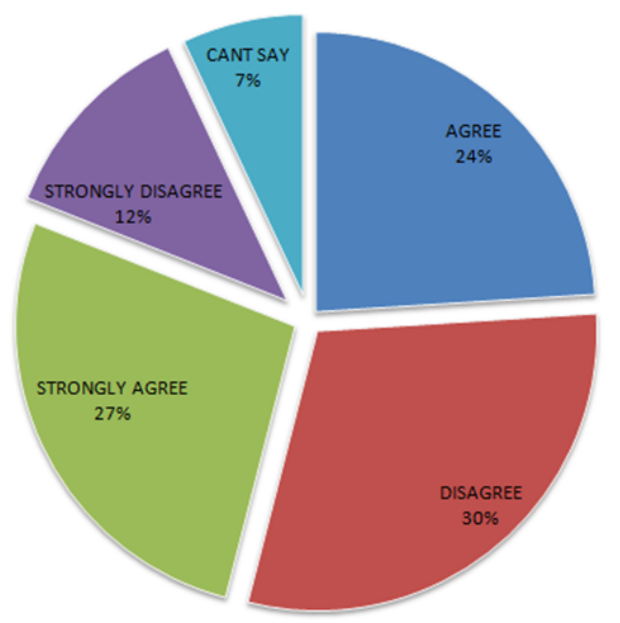

Figure 5 Response on the above mentioned reasons whether justified or not.

\section{When the respondents were asked whether honour killing revives the honour of the family}

Than 59\% disagreed and believed that honour killing doesn't revive the honour of the family and in this percentage $17 \%$ disagreed strongly making it the majority. Even if someone kills on the name of honour killing it doesn't mean that their intention is to revive the honour of the family, it can be in anger or for revenge or some other reason. To revive the honour of the family can be one of the reasons for killing but not the only reason. $32 \%$ of the respondents agree that honour killing revives the honour of the family amongst which $13 \%$ agree strongly which makes it's a minority view. $9 \%$ respondents were not aware of it or may be didn't want to comment on it so they choose the option Can't Say (Figure 6).

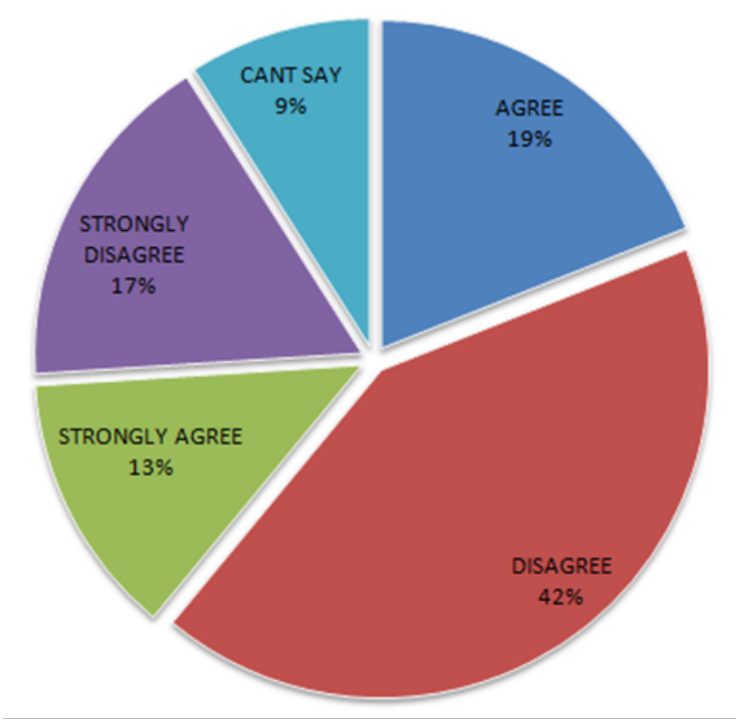

Figure 6 Response whether honour killing revives the honour of the family. 
When respondents were asked whether the honour of the family solely depends on women of the family the response was a surprise to the researcher because in this modern world were women work shoulder to shoulder with their male counter parts still $59 \%$ respondents think that honour of a family is sole responsibility of the females and in this percentage $23 \%$ strongly agree. This result shows that a strong tendency among the good number of the respondents related honour with women. Women sexuality and control of women and chastity having no extra marital affair; dressing properly, conducting once according to the expectations and knowing ones duty according to the tradition were some of the points emphasized here. $27 \%$ of the respondents disagree that only women are related with honour and the honour of the family solely depends on her shoulders. This section of society feels that men and women are equally responsible for the honour of a family as both are liable for their acts and behaviour, but as its evident from the statistics this sect of society is lesser in number (Figure 7).

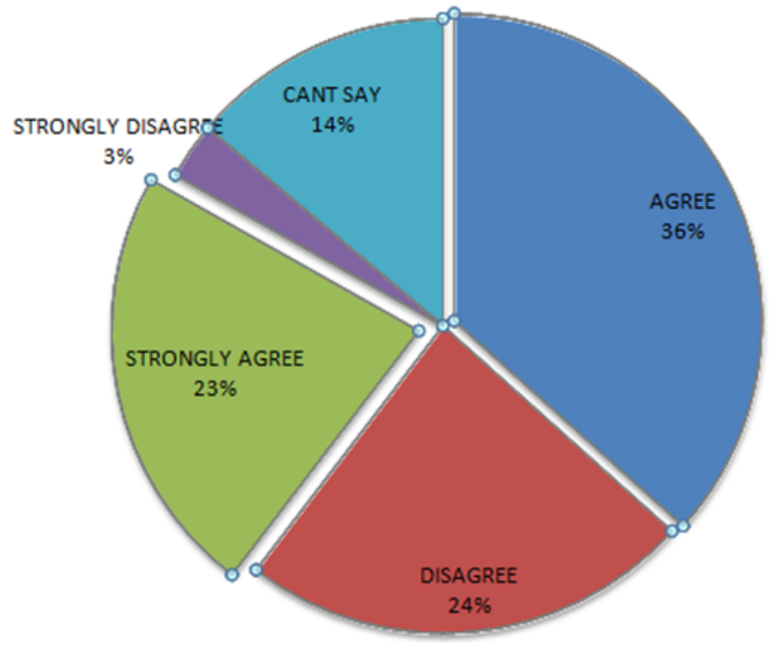

Figure 7 Response on the dependence of family honour solely on females.

When respondents were asked whether honour killing is more in uneducated families rather than in educated families, $55 \%$ agreed that it is more in uneducated families than in educated family reason being that uneducated families because of less knowledge and less exposure have no idea about the freedom of one's life which he/she lives and they think that when the person belongs to their family that means he/ she is their property so they can do any think they like. They are also unknown about the consequences which shall follow their criminal act. Maximum population which is uneducated is too close to their tradition and culture and will never leave them in any circumstances. $37 \%$ disagree and state that honour killing is not related to educated or non educated person, it only depends on the belief of a person (Figure $8)$.

When respondents were asked whether everyone has a right to live in his or her own way $67 \%$ agreed amongst which $24 \%$ strongly agreed which shows that maximum of the respondents agree to the fact that everyone has a right over their lives and they can live it in any way they like. They can live their life on their conditions and not on the dictates of others. $29 \%$ respondents have disagreed and are of the view that right to live does not include living in his/her own way as they have to live in a society and they should live according to the limits settled by a particular society and such limits are for everyone (Figure 9)

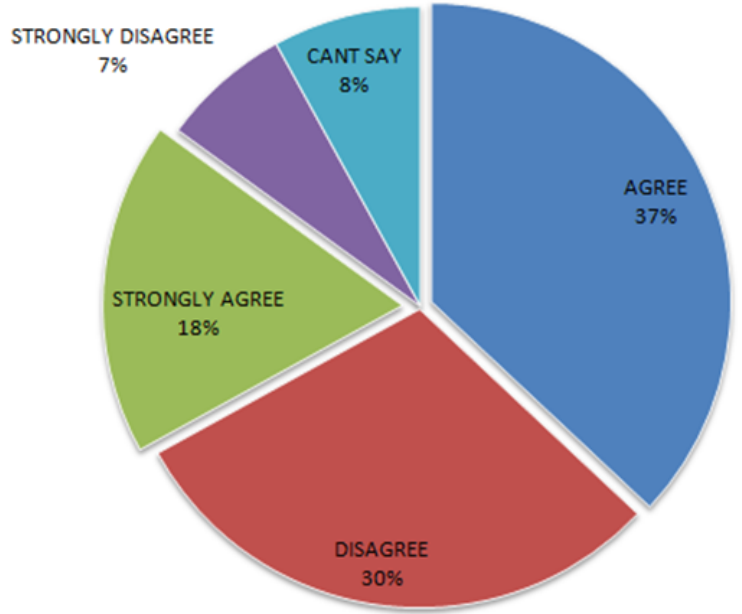

Figure 8 Represents whether honour killing is more in uneducated families rather than in uneducated families.

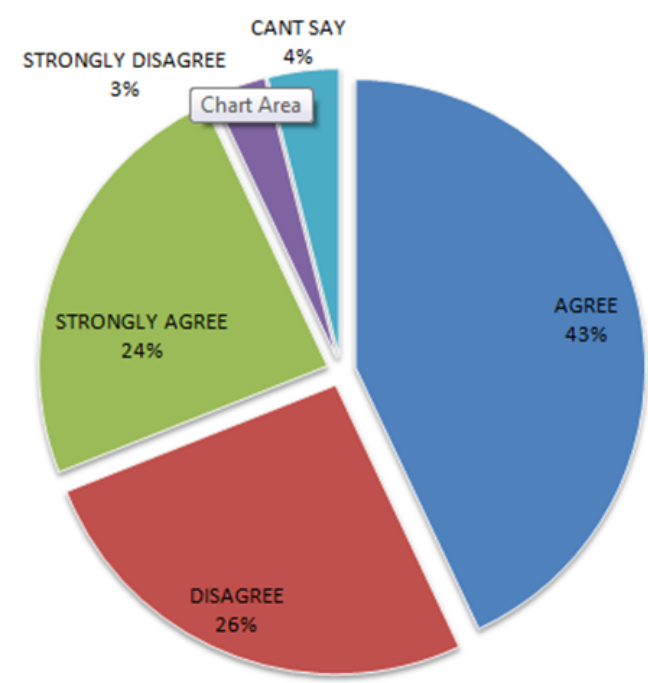

Figure 9 Response to the statement whether a person has a right to live in his/her way.

When the response was sought for the question whether everyone has a right to choose his/her career about $87 \%$ of the population agreed and this percentage included $34 \%$ of the respondents who strongly agreed making it the majority opinion of the people. This analysis proves that society is flexible when it comes to the point of career selection. Only $12 \%$ respondents think that everyone in the society doesn't have a right to have a career of her/his choose. This $12 \%$ includes specially those parents who force their children to go into a profession in which they are not interested at all but they pursue such profession only because their parents want them to be there (Figure $10)$.

When respondents were asked whether religion permits honour killing, $53 \%$ of the respondents disagreed and $45 \%$ agreed. Only $8 \%$ difference between the two makes the situation very tight. This means almost half of the society thinks religion permits honour killing and surely they can take it as a defence to defend such an act and on the other hand other half of the society is of the opinion that honour killing was never permitted by any religion (Figure 11). 


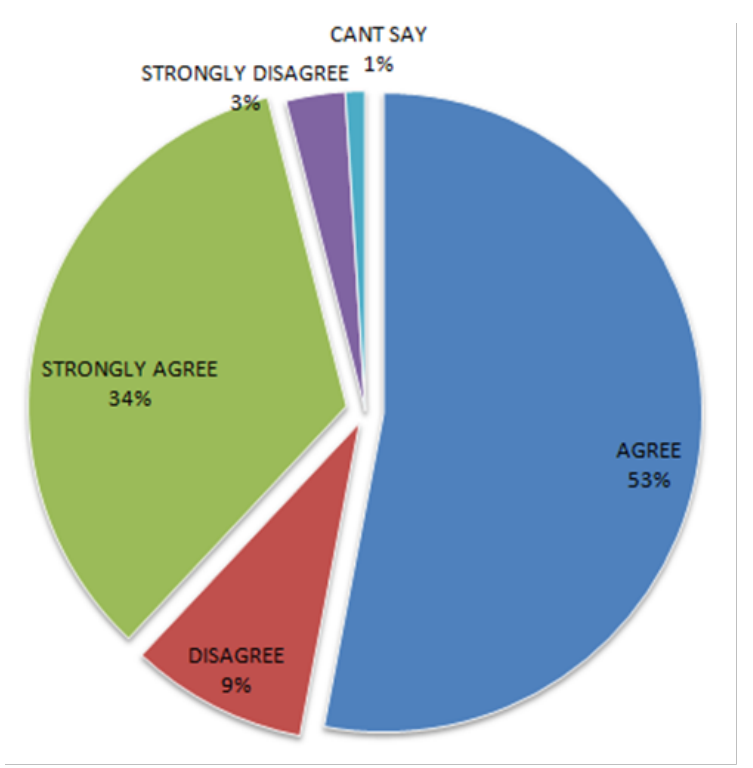

Figure 10 Response of the population on whether a person has a right to choose career.

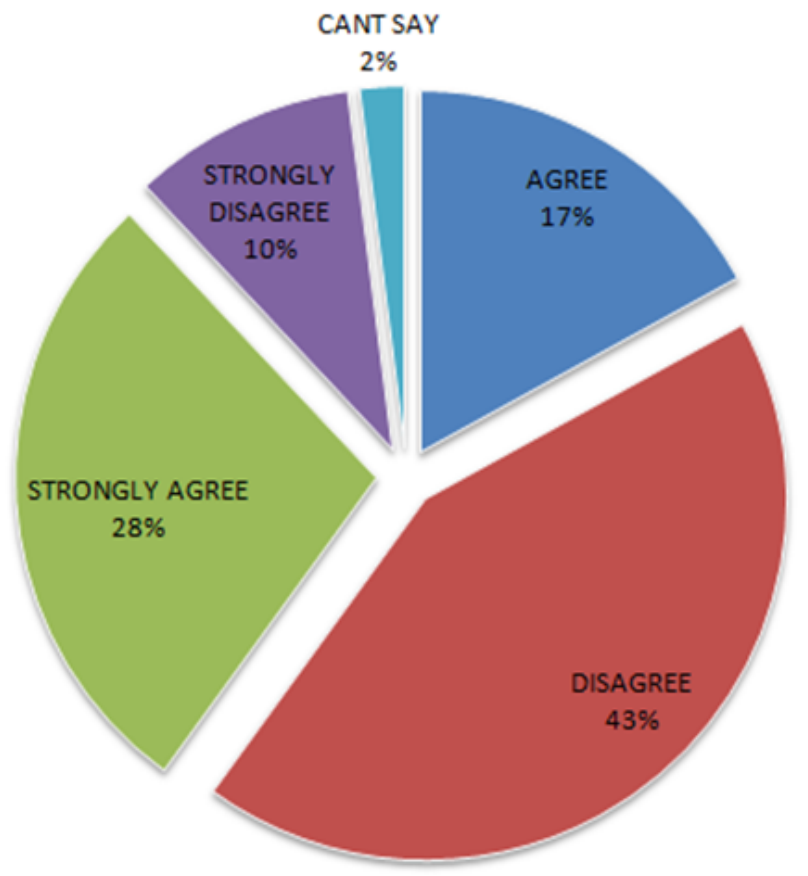

Figure I I Opinion of the respondents whether religion permits honour killing or not?

When respondents were asked that does a family member has a right to kill the person who has shame to the family or does a relative has any such right, $73 \%$ disagreed to this calming that no one has a right to kill anyone and in this percentage $32 \%$ strongly disagreed making the opinion more powerful from the point of view of the majority. $24 \%$ agreed and was of the opinion that a member has a right to kill another member of the family who has brought shame to the family (Figure 12).

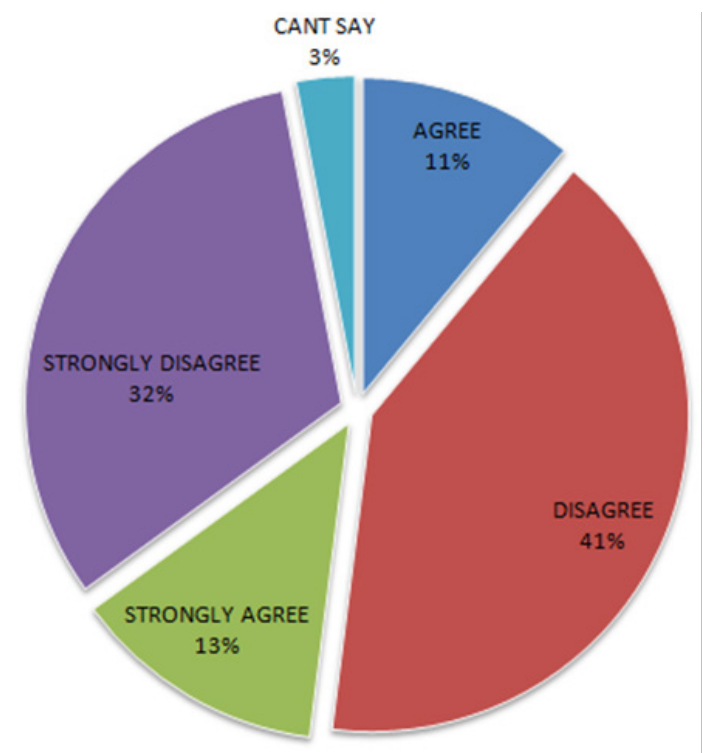

Figure 12 Responses given for the right to kill a person for honour.

When respondents were asked about the role of mohalla committees being same with that of khap panchayats which are operating in Haryana/Punjab and which is indulged in active participation in honour abuse and honour killing, the response which came was a shock for the researcher as the answers again made it a $50-50$ sitvation. $45 \%$ responded agreed and are of the opinion that mohalla committee and khap panchayats share the same role while as $46 \%$ feel that they don't share the same role and have disagreed. $9 \%$ respondents had no idea about this question so they have opted that Can't Say option. The difference between agreed and disagreed is only $1 \%$ which divides the society is equal halves (Figure 13).

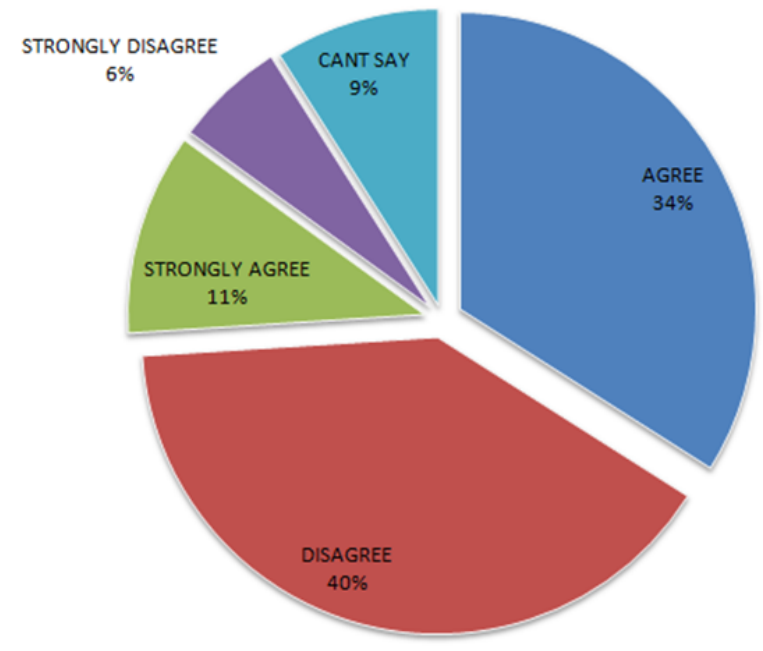

Figure I 3 Response for the role of mohalla committe.

Respondents when asked that whether the existing laws are sufficient to curtail the menace of honour killing, 53\% disagreed and have said that existing laws are not sufficient to control this crime and improvements should be made in that aspect while as $45 \%$ feel that existing laws are sufficient and no more modification is needed in them (Figure 14). 


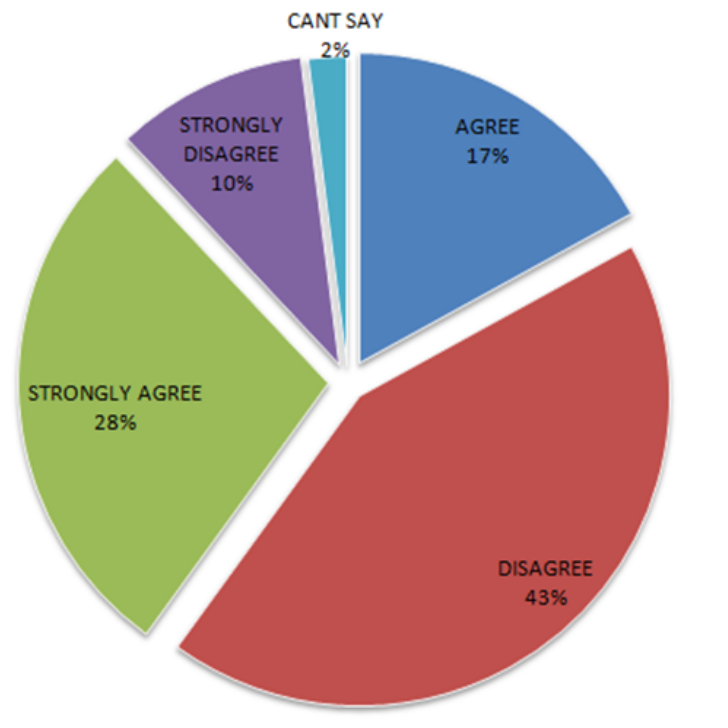

Figure 14 Opinion on the exsisting laws.

When response was sought over the statement that existing laws are implemented properly than $75 \%$ respondents disagreed and amongst which $40 \%$ of the respondents strongly disagreed and believed that the existing laws are not implemented properly and reasons can be many life corruption, delayed cases, political pressure, social stigma etc. Majority is of the opinion that the prevailing laws with respect to honour killing need better implementation because how good a law may be, is totally useless if not implemented properly. $15 \%$ agree that the implementation of law is proper and $10 \%$ being unaware of the law or its implementation choose the option Can't Say (Figure 15).

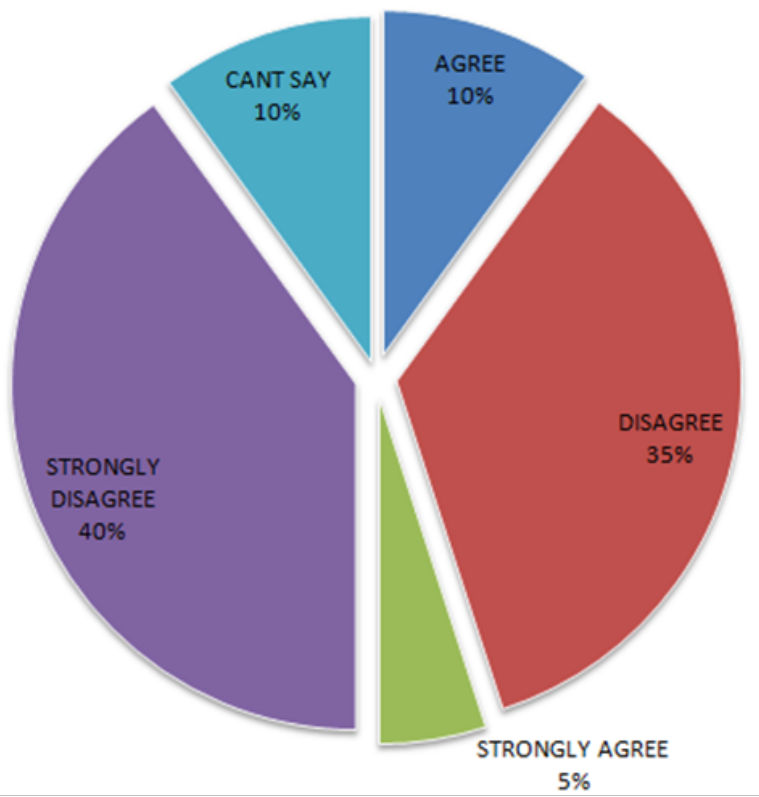

Figure I 5 Response on the implementation of the laws.

When respondents were asked about the incorporation of new laws relating to the crime of honour killing $58 \%$ agreed that new laws should be made and those laws should be incorporated properly and amongst these $42 \%$ strongly agreed on the incorporation of the new laws with regard to honour killing. These statistics make us aware of the mindset of the majority of the people who are not happy with the prevalent laws and they want introduction of the new impact full laws which will curtail the menace of honour killing. $24 \%$ of the respondents have disagreed as they think that the prevailing laws are sufficient and need not be changed. While as $18 \%$ people being unaware of the laws and their application in the courts and their impact on the people have opted themselves out from giving a concrete answer and have in fact chosen the option Can't say (Figure 16).

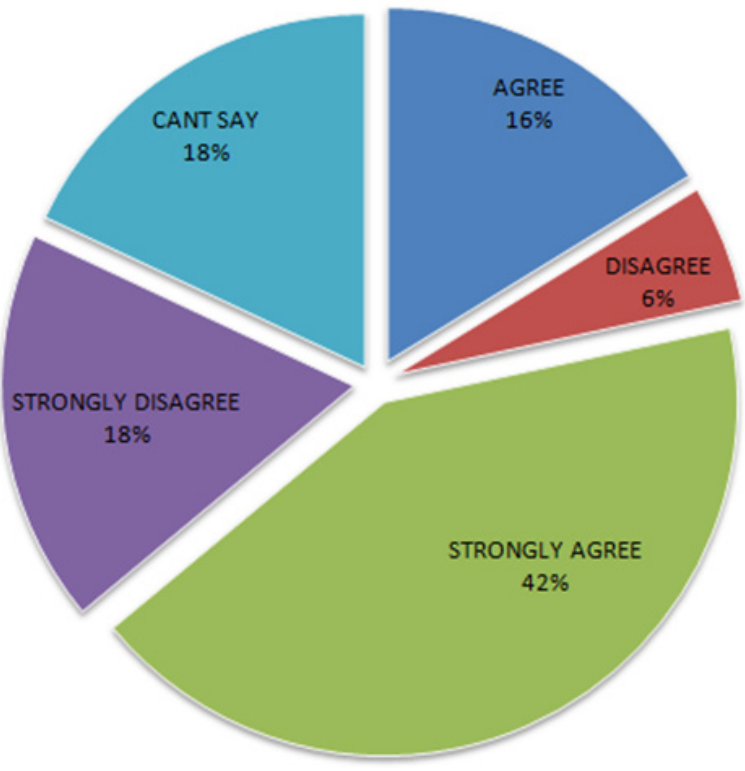

Figure 16 Opinion on the incorporation of new laws.

When response was asked for the question whether honour killing should be severely punished, $75 \%$ of the respondents have agreed and amongst which $55 \%$ have strongly agreed that the culprits involved in the heinous crime of honour killing should be punished severely and should be punished in such a way that it should act as deterrence for others and a person should think 1000 times before involving himself/ herself in such an activity. $23 \%$ of the respondents disagreed and are of the opinion that culprits of honour killing should not be severely punished (Figure 17).

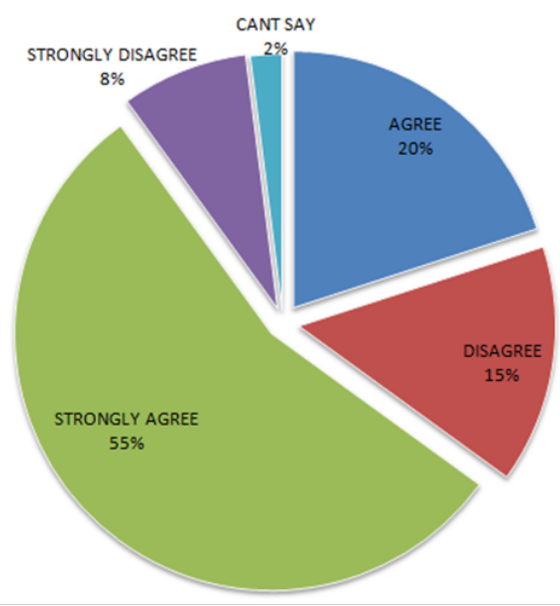

Figure 17 Response for the severability of the punishment. 
When respondents were asked whether they think that the personality of a judge can affect the judgment in the cases of honour killing, the reply was surprising as $58 \%$ of the population agrees and amongst this percentage $42 \%$ strongly agrees that the personality of the judge effects the decision of the court. According to these respondents judge is a human, he has emotions, may be at times he might place himself in the shoes of the offender/accused and then evaluate what he would have done in such a situation if the person who brought dishonour to his/her family is his/her daughter/son/any other family member. $24 \%$ respondents disagree and are of the opinion that judges have no personality of their own when they have to decide a case. They have to decide a case on the merits and de merits of each case and personality plays no role in it. Judges are on the highest seat of justice which gives them no room for emotions (Figure 18).

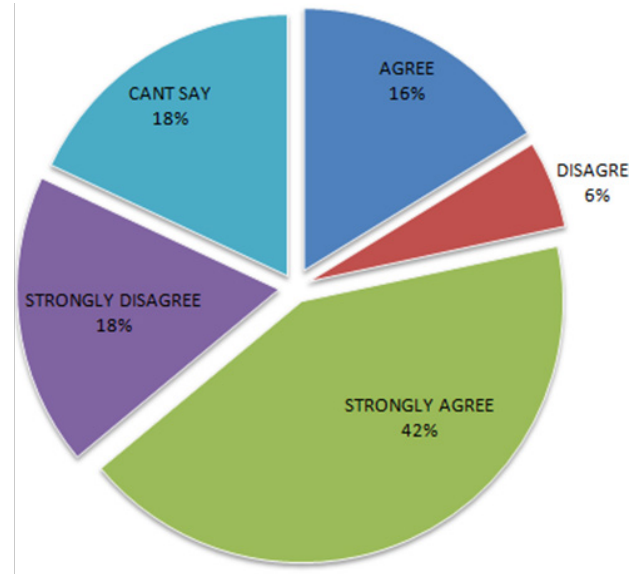

Figure I 8 Response of the respondents on the personality of the judges.

When respondents were asked whether there is any chance that honour killing might be justified in certain cases then again the response lead to 50-50 situation where $46 \%$ disagreed and $45 \%$ agreed. And other $6 \%$ remained neutral by choosing the option Can't Say. 46\% respondents think that honour killing is not justified in any case what so ever the reason may be. Killing is killing and its nature will not change with the reason of honour. Honour cannot be bigger than the life of any person while as other $45 \%$ think in the opposite direction and responded that honour is the biggest think in the life, it is bigger than the life of any person and if needed honour killing should be done in situation where you have to safe the honour (Figure 19).

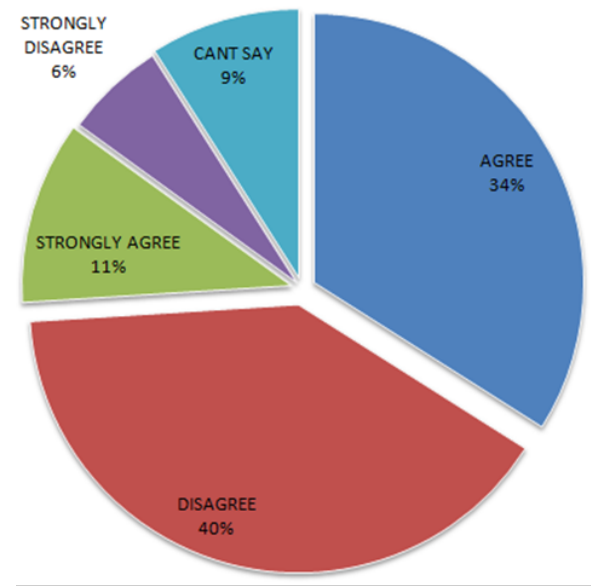

Figure 19 Opinion on the statement whether honour killing is justified in exceptional cases.

\section{Conclusion}

No doubt the outlook of people and society has changed in many ways but as the roots of past are still there in the minds of people which sometimes make their behaviour fluctuating and they contradict their own statements it is a universally accepted fact that everyone has a right to live his/her life in his/her way but then the same people who boost the fact say that a person has a right to kill his/her family member if they have brought shame to the family and to restore that honour that particular person should be eliminated. It means people are carrying two personalities in them were one is walking toward a free world and hustle free life not bound by the norms of the society and the other one is slave of the society and abides by the norms and rules made by the traditions and cultures. People still follow the tag line, "Sar kaata saktei hai laiken sar jhuka saktei nahe" (we can let our heads be chopped off but we won't bow down). A human being is so complex that no one can ever imagine what the actual personality of a person is. A human being is just like liquid, moulds himself according to the needs of his environment and society and fits in perfectly. The conflicting answer given can show clearly that people ore fully aware of what is right and what is wrong but still sometimes choose wrong to keep themselves on the right path in the eyes of the society. There is a famous line which is generally said in India time and again " Log kya kaheingay" and the same thing is said in kashmiri also that is "Lokh kyah wanan" means what will people say. These are sentences which have same meaning and have ruined so many lives which cannot be even counted. Just for the sake of the society many people ruin the future of their family member as they don't want to leave that place in society which they have acquired and when they feel that post is shaking cause of some family member they don't even hesitate to kill that person for the honour of that post/status in the society.

\section{Acknowledgements}

None.

\section{Conflict of interest}

The author declares that there is no conflict of interest.

\section{References}

1. Matthew A Goldstein. The Biological Roots of Heat of Passion Crimes and Honour Killing. Politics and Life Science. 2002;21(2):28-37.

2. Section 300. Indian Penal Code. 589 p.

3. Annavarapu, Sneha. Human Rights, Honour Killings and the Indian Law. Economic \& Political weekly. 2013;52(1):296.

4. Mulenga, Mwelwa R. A critical analysis of the viability of the reasonable man test in the defence of provocation; $2013.67 \mathrm{p}$.

5. V N Shukla. Constitution of India. 12th ed. USA: Eastern Book Co; 2013. $1448 \mathrm{p}$.

6. Harries CJ. Anwar Ali Sarkar vs The State of West Bengal; 1951. 79 p.

7. VN Shukla, $87 \mathrm{p}$.

8. Robert Fisk. Relatives with blood on their hands, The Independent; 2010.

9. Puneet Kaur Grewal. Honour Killings and Law in India. IOSR Journal Of Humanities And Social Science. 2012;5(6):28-31.

10. Act No.9 of 1857 .

11. Act No. 43 of 1954.

12. Act No. 33 of 1989. 
13. Act No. 43 of 2005.

14. Act No. 1 of 1872.

15. Gill, Aisha K. Feminist Reflections on Researching so-called "Honour killing. Feminist legal studies. 2013;21:241-261.

16. Dogan, Recep. Honour killing in the UK communities: Adherence to Tradition and resistance to change. Journal of Muslim Minority Affairs. 2013;33(3):401-417.

17. Julian Pitt. Cultural, Honour, and Social Capital. The Concept of Honour. Economic \& Political Weekly. 2013;48(18):73.

18. Manoj Babli Case.

19. Krishna Master and anr. UP:(AIR 2010 SC 3071).

20. Lata Singh. UP\& Anr. (AIR 2006 SC 2522).

21. Fiaz ahmed Anger vs State 2009 (3) RAJ 692.
22. Jyoti Alias Jannat and Anr v. UP: (2006) 5 SCC 47534 (2011) 6 SCC 405.

23. 34 (2011) 6 SCC 405 .

24. Bhagwan Dass v. State of NCT of Delhi, ((2011) 6 SCC 396).

25. Arumugam Servai v. State of Tamil Nadu ((2011)6 SCC 405.

26. Lata Singh vs. State of U.P. and Anr, (AIR 2006 SC 2522) .

27. Prevention of Interference with the Freedom of Matrimonial Alliances (in the name of Honour and Tradition): A Suggested Legal Framework. Report No.242.

28. AIR 2013 SCR at 238.

29. IBN Times.co.in, November 25, 2013.

30. Bhawna Yadav: Small dreams of Delhi 'honour killing' victim. UK: BBC; 2014.

31. HC Orders ASI to protect Borivali caves. Mumbai: dnaindia; 2018. 